\title{
Using Real Time PCR for the Etiological Diagnosis of Viral Encephalitis
}

\section{Cristian H Corio ${ }^{1}$, Ivana L Primost ${ }^{1}$, Hugo G Pitocco ${ }^{1}$, José L Pérez ${ }^{1}$ and Carlos J Rubinstein ${ }^{2 *}$}

${ }^{1}$ Genetics degree, Staff at Molecular Genetics Service, Hospital Dr. Federico Abete, Municipio de Malvinas Argentinas, Bs. As. República Argentina ${ }^{2}$ Head of Teaching and Research, Hospital Dr. Federico Abete, Municipio de Malvinas Argentinas, Bs. As. República Argentina

\begin{abstract}
Viral infections of the central nervous system (CNS) represent a challenge for early diagnosis and proper treatment of the disease. Different studies should be performed on the patient in order to arrive at an accurate diagnosis. The electroencephalogram, magnetic resonance imaging, viral culture, serological and cytochemical analysis are important tools to diagnose this disease. However, the polymerase chain reaction (PCR) or conventional PCR has become the gold standard for the diagnosis of viral encephalitis. Indeed, Real Time PCR (RT-PCR) equipments are replacing the conventional PCR ones. Faster results may be an explanation of this fact.
\end{abstract}

Information obtained from dissociation curve analysis of the RT-PCR technique represents a highly sensitive and specific tool for the Herpes simplex (HSV), Varicela (VZV), Cytomegalovirus (CMV) and Enterovirus (EV) detection.

\section{Introduction}

Infections of the cerebral parenchyma cause the inflammation called encephalitis. Infectious agents most frequently found in these encephalitides are viruses, such as HSV, VZV, CMV and EV [1-3]. Viruses can cause an encephalitis by direct invasion of brain tissue or by post-infectious inflammatory type processes. Several factors influence the epidemiology of viral encephalitis, such as age, immunocompetence of the patient, geographic location, weather conditions and seasonal time of the year. Early diagnosis is crucial in these pathologies because of the potential serious consequences for the CNS [4-8].

Cerebrospinal fluid (CSF) analysis is a key tool in the diagnosis of CNS viral infections. Classical methods for the detection and subtyping of virus infections include enzyme-linked immunosorbent assay (ELISA), immune fluorescence microscopy (IFI) and isolation of the virus in cell cultures. However, at present, PCR has become the gold standard for the rapid diagnosis of viral encephalitis. Moreover, RT-PCR, a modification of this technique, is being adopted as main method for detection of these viral agents. Faster results, higher sensibility, and the relative lack of complexity of the method would be explanations for this fact [1-4].

In the Molecular Biology Laboratory within Dr Federico Abete Hospital, from Malvinas Argentinas, we've implemented a methodology for the detection of HSV 1-2, VZV, CMV and EV in CSF samples obtained from patients with a clinical encephalitis diagnosis treated during 2012.

\section{Materials and Methods}

\section{Clinical samples}

CSF samples used for our in-house technique validation were provided by Hospital Dr. Federico Abete Pediatric and Adult Intensive Care Units (ICUs), during 2012. They were all from patients with a clinical viral encephalitis diagnosis. Technicians processing samples only had access to them through code numbers. Every positive control sample was checked in 2 serial dilutions ( 10 fold) to verify amplification reaction efficiency.

\section{Positive and negative controls}

Positive control for EV (culture) and VZV (plasmid) were provided by ANLIS (Administración Nacional de Laboratorios e Institutos de Salud). Positive controls for HSV 1-2 and CMV were developed in our laboratory through samples that were tested as positive in outsourcing laboratories.

Negative control samples were CSF that tested as negative in cytochemical and PCR tests performed in outsourcing laboratories (data not shown).

\section{Nucleic acid extraction}

DNA and RNA obtention was accomplished with the commercial kit QUIAamp RNA Viral MiniKit (Quiagen). It was used according to manufacturer instructions. This commercial kit guarantees the lack of inhibitory elements in resuspended nucleic acids.

\section{PCR oligonucleotide primers}

For VZV RT-PCR amplification reaction, ANLIS proposed primers were used [9]. For HSV 1-2 \& CMV, we tested three different pairs of primers extracted from bibliography $[9,10]$. EV RT-PCR detection was carried out with primers reported by Rotbart in 1990 $[11,12]$. Table 1 shows primers base composition, expected fragment length and amplicons melting temperature $\left(\mathrm{T}_{\mathrm{m}}\right)$.

\section{Setting up RT-PCR reaction}

For these assays we used 15 positive samples for HSV 1-2, 11 for VZV, 8 for CMV and 12 for EV. Each virus RT-PCR detection reaction was carried out in simplex PCR. For running all four reactions simultaneously, and considering differences in primers annealing temperatures, we used thermal cycler Exicycler 96 (Bioneer) with programmable temperature gradient and placed each reaction in the appropriate place of the block.

Cycling conditions were set through RunExicycler3 (Bioneer)

*Corresponding author: Carlos $\mathrm{J}$ Rubinstein, Head of Teaching and Research Laboratorio de Genética y Biología Molecular, Hospital Dr. Federico Abete Municipio de Malvinas Argentinas, Bs. As. República Argentina, E-mail rubidoc@gmail.com

Received February 17, 2013; Accepted July 14, 2013; Published July 16, 2013

Citation: Corio CH, Primost IL, Pitocco HG, Pérez JL, Rubinstein CJ (2013) Using Real Time PCR for the Etiological Diagnosis of Viral Encephalitis. J Neurol Disord 2: 124. doi:10.4172/2329-6895.1000124

Copyright: @ 2013 Corio $\mathrm{CH}$, et al. This is an open-access article distributed under the terms of the Creative Commons Attribution License, which permits unrestricted use, distribution, and reproduction in any medium, provided the original author and source are credited. 
Citation: Corio CH, Primost IL, Pitocco HG, Pérez JL, Rubinstein CJ (2013) Using Real Time PCR for the Etiological Diagnosis of Viral Encephalitis. J Neurol Disord 2: 124. doi:10.4172/2329-6895.1000124

Page 2 of 3

\begin{tabular}{|c|c|c|c|c|c|}
\hline Virus & Forward primer 5' - 3' & Reverse primer 5' - 3' & Primer Annealing & $\begin{array}{l}\text { Amplicon size } \\
\text { (bp) }\end{array}$ & $\begin{array}{l}\text { Amplicon } \\
\text { Melting }\left({ }^{\circ} \mathrm{C}\right)\end{array}$ \\
\hline Varicela Zoster & TGAGGGGATAGCTAAAATCG & TATAAAAGTTTTTTCACACTC & 55 & 97 & 79 \\
\hline Cytomegalovirus & ATAGGAGGCGCCACGTATTC & TACCCCTATCGCGTGTGTTC & 58 & 256 & 84 \\
\hline Enterovirus & GGCCCCTGAATGCGGCTAAT & ATTGTCACTGGATGGCCAAT & 56 & 198 & 85 \\
\hline Herpes Simplex 1/2 & CCATACCGACCACACCGACGA & CATACCGGAACGCACCACAC & 68 & 331 & 92 \\
\hline
\end{tabular}

Table 1: Primer sets used in these assays.

\begin{tabular}{|l|l|l|l|l|}
\hline & HSV 1 and 2 & VZV & CMV & EV \\
\hline Positives & 13 & 11 & 8 & 12 \\
\hline Negative & 132 & 85 & 71 & 113 \\
\hline Total: & 145 & 96 & 79 & 125 \\
\hline
\end{tabular}

Table 2: Detection of HSV 1-2, CMV, VZV and EV from CSF samples in Hospital Dr Federico Abete Molecular Biology Lab in 2012.

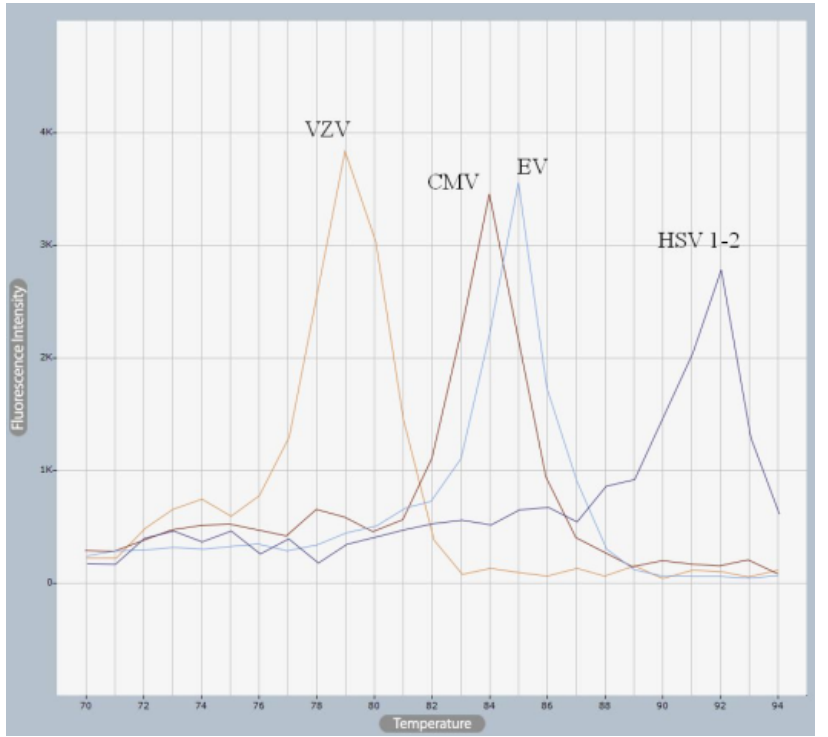

Figure 1: Melting curves analysis of the amplified fragments generated by RTPCR using positive controls. Each virus melting temperature displayed in the figure.

software: a first step of retrotranscription, necessary only for EV, initial denaturation of $95^{\circ} \mathrm{C}$ for $5 \mathrm{~min}$ and 45 cycles of a two-step reaction of denaturation at $95^{\circ} \mathrm{C}$ for 5 seconds; annealing/extension/ data collection for 30 seconds. Finally, melting curve analysis initiates at $60^{\circ} \mathrm{C}$ to $94^{\circ} \mathrm{C}$ with a ramp temperature of $1^{\circ} \mathrm{C}$ per second (for primers annealing and amplicon melting data, refer to Table 1). Analysis Exicycler 3 (Bioneer) was the software used for obtaining results data and for analyzing them, as well.

\section{Reaction mix components}

Every RT-PCR reaction was set using SYBRGreen DNA binding dye. Commercial mix KAPA SYBR ${ }^{\circledR}$ FAST One-Step qRT-PCR Universal (KAPPA Biosystem. Cat $\mathrm{N}^{\circ} \mathrm{KK} 4650$ ) was used in EV amplification reaction. KAPA $\mathrm{SYBR}^{\circledR}$ FAST Universal $2 \mathrm{X}$ qPCR Master Mix (KAPPA Biosystem Cat $\left.\mathrm{N}^{\circ} \mathrm{KK} 4600\right)$ was the reaction mix for HSV 1-2, VZV and CMV amplification reaction. Reactions were set in a total volume of $25 \mu \mathrm{l}$ and $0.4 \mu \mathrm{M}$ of primers, according manufacturer's instructions.

\section{Dissociation curves}

Amplification curves and dissociation rate analyses were run in Analysis Exicycler 3 (Bioneer). These curve analyses determine dissociation kinetics in the nucleic acids of amplified fragments. This is the procedure to get the corresponding Tm to each fragment, and to verify RT-PCR reactions specificity. Verification of proper amplification was made running amplification products using electrophoresis in agarose gels (data not shown).

\section{Results}

\section{Dissociation curve analysis}

Figure 1 shows peaks for each virus. HSV 1-2 showed a peak in $92^{\circ} \mathrm{C}, \mathrm{VZV}$ in $79^{\circ} \mathrm{C}, \mathrm{CMV}$ in $84^{\circ} \mathrm{C}$ and $\mathrm{EV}$ in $85^{\circ} \mathrm{C}$.

\section{RT-PCR reaction performance}

Serial dilution experiments showed positive results even in 1:100 dilution rate for all samples. This allowed us to augment the number of samples analyzed and to check RT-PCR reaction performance in clinical samples with low viral genetic load.

\section{Clinical samples}

445 RT-PCR reactions were performed in CSF samples from Intensive Care Unit patients of this hospital, during the entire 2012. From this amount, we obtained 44 samples showing positive results and 401 negative, representing the following positivity: $2.93 \%$ HSV (13/445), 2.47\%-VZV (11/445), CMV-1.79\% (8/445), EV-2.69\% (12/445) (Table 2).

\section{Discussion}

Nucleic acids detection through in vitro cloning in thermal cyclers has drastically modified diagnostic methodologies in hospitals. This method, known as PCR, has allowed the detection of hard to culture pathogens for traditional microbiological laboratories [13-17]. Even though this technique just exposes the presence of genetic material of the procured microorganism (this not implying evidence of the presence of a viable organism), PCR has been demonstrated to be quite useful when is together with an appropriate clinical approach.

Clinical relevance of early detection of infectious viral agents in CNS, turns valuable this innovation in diagnosing viral encephalitis by HSV 1-2, VZV, CMV and EV.

Having access to a thermal cycler with gradient function enables one to run the RT-PCR reaction for the set of four viruses simultaneously. This allowed our laboratory to provide a service of viral diagnosis in few hours (less than four 4 hours since the arrival of the sample).

\section{Conclusions}

According to the results obtained in this work, RT-PCR technique, together with dissociation curve analysis, is a highly sensitive and specific tool for detecting HSV, VZV, CMV and EV in clinical samples.

This molecular methodology gains access to important information during medical assistance and therapeutic decisions. 
Citation: Corio CH, Primost IL, Pitocco HG, Pérez JL, Rubinstein CJ (2013) Using Real Time PCR for the Etiological Diagnosis of Viral Encephalitis. J Neurol Disord 2: 124. doi:10.4172/2329-6895.1000124

Its usefulness in epidemiology and hence in prevention of this kind of infectious diseases is given by the direct conversion of laboratory results in hospital statistical numbers.

In a context of a developing region, El Municipio de Malvinas Argentinas (Pcia. de Buenos Aires, República Argentina) set up a molecular biology laboratory inside of Hospital Dr. Federico Abete. This lab provided early diagnosis to ICUs. While writing this paper almost 250 suspected cases of viral encephalitis have been solved in a period of almost one year.

\section{References}

1. Ziai WC, Lewin JJ 3rd (2008) Update in the diagnosis and management of central nervous system infections. Neurol Clin 26: 427-468, viii.

2. Schmutzhard E (2001) Viral infections of the CNS with special emphasis on herpes simplex infections. J Neurol 248: 469-477.

3. Parikh V, Tucci V, Galwankar S (2012) Infections of the nervous system. Int $J$ Crit IIIn Inj Sci 2: 82-97.

4. Pollak L, Dovrat S, Book M, Mendelson E, Weinberger M (2012) Varicella zoster vs. herpes simplex meningoencephalitis in the PCR era. A single center study. J Neurol Sci 314: 29-36

5. Archimbaud C, Chambon M, Bailly JL, Petit I, Henquell C, et al. (2009) Impact of Rapid Enterovirus Molecular Diagnosis on the Management of Infants, Children, and Adults with Aseptic Meningitis. Journal of Medical Virology 81: 42-48

6. Ramers C, Billman G, Hartin M, Ho S, Sawyer MH (2000) Impact of a diagnostic cerebrospinal fluid enterovirus polymerase chain reaction test on patient management. JAMA 283: 2680-2685.

7. DeBiasi RL, Tyler KL (1999) Polymerase chain reaction in the diagnosis and management of central nervous system infections. Arch Neurol 56: 12151219 .
8. Cinque P, Bossolasco S, Lundkvist A (2003) Molecular analysis of cerebrospinal fluid in viral diseases of the central nervous system. J Clin Virol 26: 1-28.

9. Tenorio A, Echevarría JE, Casas I, Echevarría JM, Tabarés E (1993) Detection and typing of human herpesviruses by multiplex polymerase chain reaction. J Virol Methods 44: 261-269.

10. Allen RD, Pellett PE, Stewart JA, Koopmans M (1995) Nonradioactive PCR-enzyme-linked immunosorbent assay method for detection of human cytomegalovirus DNA. J Clin Microbiol 33: 725-728.

11. Rotbart HA (1990) Enzymatic RNA amplification of the enteroviruses. J Clin Microbiol 28: 438-442.

12. Hymas WC, Aldous WK, Taggart EW, Stevenson JB, Hillyard DR (2008) Description and validation of a novel real-time RT-PCR enterovirus assay. Clin Chem 54: 406-413

13. Fujimoto T, Izumi H, Okabe N, Enomoto M, Konagaya M, et al. (2009) Usefulness of Real-Time Reverse Transcription-polymerase chain reaction for the diagnosis of echovirus aseptic meningitis using cerebrospinal fluid Jpn J Infect Dis 62: 455-457.

14. Shoja ZO, Tabatabie H, Shahmahmoudi S, Nategh R (2007) Comparison of cell culture with RT-PCR for enterovirus detection in stool specimens from patients with acute flaccid paralysis. J Clin Lab Anal 21: 232-236.

15. Terletskaia-Ladwig E, Metzger C, Schalasta G, Enders G (2000) Evaluation of enterovirus serological tests IgM-EIA and complement fixation in patients with meningitis, confirmed by detection of enteroviral RNA by RT-PCR in cerebrospinal fluid. J Med Virol 61: 221-227.

16. Santos AP, Costa EV, Oliveira SS, Souza MC, Da Silva EE (2002) RT-PCR based analysis of cell culture negative stools samples from poliomyelitis suspected cases. J Clin Virol 23: 149-152.

17. Leparc I, Aymard M, Fuchs F (1994) Acute, chronic and persistent enterovirus and poliovirus infections: detection of viral genome by seminested PCR amplification in culture-negative samples. Mol Cell Probes 8: 487-495. 